\title{
ECONOMIC EVALUATIONS OF DAMAGES FROM PREMATURE MORTALITY CAUSED BY RESPIRATORY DISEASES
}

Davydenko A.M., Petrosian A.A., Blyzniuk V.V. ЕКОНОМПЧНІ ОЦПНКИ ЗБИТКІВ ВІД ПЕРЕДЧАСНӦ̈ СМЕРТНОСТІ ВНАСЛДОК ЗАХВОРНВАНЬ ДИХАЛЬНИХ ШЛЯХІВ

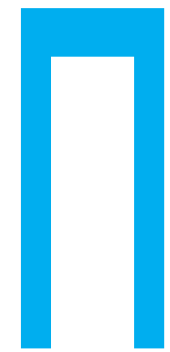

ДАВИДЕНКО Г.М., ПЕТРОСЯН А.А., БЛИЗНЮК В.В.

ДУ «Інститут громадського здоров'я ім. О.М. Марзєєва НАМНУ», М. Київ,

«Інститут економіки та прогнозування НАНУ», м. Київ

УДК 314.4 : 368.025 .7

Ключові слова: передчасна смертність, атмосферне повітря, вартість людського життя, економічна оцінка. ротягом життя людина постійно перебуває під впливом різноманітних фізичних, хімічних, біологічних та соціальних факторів, що постійно змінюються за своєю інтенсивністю та тривалістю впливу. 3 появою нових виробництв, технологій, хімічних сполук перед гігієною як наукою, що вивчає систему «людина середовище», з'являються нові виклики, які потребують оцінки безпеки довкілля.

У свою чергу, гігієна розглядає людину не тільки як організм, а саме як сукупність усіх біологічних та соціальних відносин. I для кожного індивідуума така сукупність має свою цінність.

Відповідно до цього виникає потреба у проведенні кількісних оцінок втрачених можливостей через захворюваність та смертність населення. Це, у свою чергу, кореспондується з поняттями соціально-економічних збитків.

У цивілізованих країнах життя визнається безцінним. Стаття 3
Конституції України також визнає людину та її життя і здоров'я, недоторканність і безпеку найвищою соціальною цінністю, тобто держава на законодавчому рівні визнає свій обов'язок захищати ці цінності.

В Україні існує нормативна база для виплат компенсацій загиблим та постраждалим громадянам внаслідок різних подій, але при цьому відсутня законодавчо встановлена ціна життя, яка могла б бути основою розрахунку суми страхової компенсації. Соціальні збитки населення розглядаються з точки зору втрати здоров'я та, як наслідок, погіршення якості життя, поширення захворювань тощо. Економічні збитки дозволяють перевести соціальні збитки у числовий вираз, тобто це ті втрати, якими можна оцінити їхню вартість. Таким чином, актуальність дослідження зумовлюється необхідністю обґрунтування методологічних підходів до здійснення еконо-
ЭКОНОМИЧЕСКИЕ ОЦЕНКИ УЩЕРБОВ ОТ ПРЕЖДЕВРЕМЕННОЙ СМЕРТНОСТИ ВСЛЕДСТВИЕ ЗАБОЛЕВАНИЙ ДЫХАТЕЛЬНЫХ ПУТЕЙ Давиденко А.Н., Петросян А.А., Близнюк В.В. ДУ «Институт общественного здоровья им А.Н. Марзеева НАМНУ», Г. Киев

Институт ЭКОНОМИки и прогнозирования НАНУ, г. Киев Целью исследования является осуществление стоимостной оценки ущербов в экономике Украины от преждевременной смертности, обусловленной заболеваниями дыхательных путей. Материалы и методы. Социальные ущербы населения, связанные с заболеваемостью дыхательных путей, рассматриваются с точки зрения потерь здоровья и, как следствие этого, ухудшения качества жизни, распространения заболеваемости и смертности. Экономические ущербы позволяют представить социальные ущербы в числовом выражении. Важной составляющей при проведении таких расчетов является оценка стоимости жизни и утраченных потенциальных лет жизни в результате преждевременной смерти. Указанные расчеты проводились с использованием сравнительного, медико-статистического, демографического, экономико-математического методов исследования, метода группировки и структурно-логического анализа. При этом использовались официальные статистические данные Министерства здравоохранения Украины, Государственной службы статистки и Фонда социального страхования Украины за

\section{0-2015 годы}

Результаты. Нами проведена оценка потерянных потенциальных лет жизни вследствие преждевременной смерти по классам болезней, связанные с органами дыхательной системы.

Полученные данные свидетельствуют о том, что существенную часть в общем количестве потерь потенциальных лет жизни составляют смерти вследствие пневмонии (6,2\%), злокачественных образований трахеи, бронхов и легких $(35,6 \%)$, хронических заболеваний нижних дыхательных путей (10,4\%). В среднем по всем выбранным заболеваниям на один смертный случай теряется 8,87 лет потенциальной жизни. Проведенные расчеты количественных оценок потерь потенциальных лет жизни с использованием показателя отдачи от использования человеческого капитала в качестве стоимостной оценки человеческой жизни (в 2015 г. - 46413 грн., или 2124,7 дол. США) позволили получить сумму экономических потерь - 11,4 млрд. грн., или 523,8 млн. дол. США.

При использовании поэлементного подхода к данным 2015 г. экономические потери государства вследствие преждевременной смертности за счет заболеваемости органов дыхания составили 1,2\% ВВП, или 24,03 млрд. грн.

Ключевые слова: преждевременная смертность, атмосферный воздух, стоимость человеческой жизни, экономическая оценка. 
мічних оцінок втрат через смертність.

Для оцінки ймовірності виникнення небажаних ефектів з боку здоров'я населення, зумовлених забрудненням довкілля (зокрема атмосферного повітря), використовують методологію оцінки ризику.

Вона дозволяє не тільки оцінити та проаналізувати небезпечний вплив потенційно небезпечних речовин на здоров'я населення за гострого і хронічного інгаляційного впливу, але й обґрунтувати розробку медикоекологічних рекомендацій 3 управління якістю атмосферного повітря у світі, розробити пропозиції щодо гармонізації гігієнічних нормативів відповідно до вимог міжнародного законодавства (ВОО3, економічна комісія $€ C)$, оцінити соціальні втрати населення і побудувати профілактику шкідливого впливу.

Метою даного дослідження $\epsilon$ здійснення вартісних оцінок втрат економіки України через передчасну смертність, спричинену захворюваннями дихальних шляхів, що безпосередньо пов'язані з якістю атмосферного повітря.

Матеріали та методи дослідження. Для дослідження було використано офіційні статистичні дані МO3, Державної служби статистики та Фонду соціального страхування України з тимчасової втрати працездатності за період 2010-2015 рр. з застосуванням порівняльного, медико-статистичного, демографічного, економікоматематичного методів дослідження, методу групувань, структурно-логічного аналізу.

Найбільш розробленим у страхових компаніях $є$ механізм виплати за страховими подіями у професійній діяльності та на транспорті. Допомога сплачується одноразово у 100-кратному розмірі прожиткового мінімуму, встановленого для працездатних осіб на час виплати цієї суми (до грудня 2016 р. це дорівнювало 121,8 тис. грн. на сім'ю) [1].

Як будь-яка виплата у страхуванні, виплати, пов'язані з заподіяною життю та здоров'ю шкодою, базуються на поняттях теорії ризику. Ціна ризику $€$ основою соціально-економічних збитків через втрату здоров'я та життя населення внаслідок будь-яких подій. Ця концепція передбачає лінійний зв'язок між натуральними результуючими показниками (колективний або популяційний ризик смерті, натуральні втрати у вигляді років життя у населення, що мешкає в умовах ризику) та соціально-економічними втратами внаслідок шкідливого впливу на здоров'я населення.

Вартісна величина ризику для здоров'я та життя не є вартістю індивідуального життя або втратами, пов'язаними зі смертю конкретної людини, а $€$ кількісним виразом ризику, розподіленим між усіма представниками популяції, що перебуває під впливом ризику. Тому, визначивши можливий вартісний еквівалент ризику і поділивши його на обсяг популяції, що піддається ризику, можемо отримати так звану вартість середньостатистичного життя. На сьогодні це поняття використовується у багатьох теоретичних та практичних аспектах різних сфер життєдіяльності [2-4]. Проте незважаючи на підвищений інтерес до цього питання воно ще й досі не набуло законодавчого врегулювання.

Методологічні відмінності в оцінюванні вартості середньостатистичного життя (value of a statistical life, VSL) у різних країнах пояснюються використанням різних методів розрахунків, які залежать від цінності людського життя і здоров'я у рейтингу політичних пріоритетів; усвідомленням масштабу проблеми, яка $€$ ризиком для здоров'я та життя людей, повноти, достовірності та доступності статистичної інформації про ризиковані події.

Методики оцінки вартості життя можна поділити на три групи: ті, що базуються на визначенні розміру страхових виплат постраждалим; що об'єднують підходи соціально-економічних досліджень у частині людського капіталу; ті, які можна об'єднати у так звану групу «готовності платити». Жоден з існуючих методів не може вважатися абсолютно точним, тож для визначення загальнодержавних підходів слід застосовувати комбінацію цих підходів і методів.

3 метою отримання об'єктивних оцінок щодо розміру макроекономічних втрат через погіршення якості атмосферного повітря доцільно було б вирішити такі завдання:

визначити перелік показників, які найбільш повно враховуватимуть ці втрати (наприклад додаткова смертність, захворюваність, інвалідність та інші зміни стану здоров'я);

- здійснити компаративний аналіз факторів ризику забруднення атмосферного повітря для здоров'я населення;

口 отримати грошові оцінки показників здоров'я населення, які раніше були описані у натуральних показниках.

Економічні збитки через погіршення здоров'я та передчасну смерть внаслідок дії забруднюючих речовин атмосферного повітря проявляються у кількісних показниках грошових витрат на різних рівнях: макро-, мезорівні та рівні окремих домогосподарств. До складу таких витрат входять витрати на лікування, у зв'язку зі смертністю та інвалідністю, а також втрати через недоотримані обсяги виробництва у зв'язку з передчасною смертю або хворобами. Соціальні збитки пов'язані з погіршенням якості життя загалом та безпосередньо трудового життя.

Оцінити соціально-демографічні втрати, пов'язані з передчасною смертністю, можна за допомогою обсягу втрачених потенційних років життя, тобто потенційного життя, недожитого через передчасну смерть. Передчасна смертність в Україні, особливо у чоловіків працездатного віку, суттєво перевищує аналогічні показники європейських країн.

Соціально-економічне значення окремих причин смерті визначається не лише абсолютною кількістю смертей та їхньою значущістю у структурі смертності, але й впливом на оцінену у роках потенційного життя величину незворотних втрат через смертність. Різні причини зумовлюють різну величину внеску у скорочення середньої очікуваної тривалості життя населення. Тому розрахунок обсягу і структури втрачених років потенційного життя дає змогу оцінити міру впливу передчасної смертності загалом та відносну значущість окремих причин смерті у фор- 
ECONOMIC EVALUATIONS OF DAMAGES FROM PREMATURE MORTALITY CAUSED BY RESPIRATORY DISEASES

Davydenko A.M., Petrosian A.A., Blyzniuk V.V.

SI "O.M. Marzeiev Institute for Public Health, National Academy of Medical Sciences of Ukraine", Kyiv Institute for Economics and Forecasting, National Academy of Sciences of Ukraine, Kyiv

Objective. We performed a cost evaluation of the losses in the economy of Ukraine from premature mortality caused by respiratory diseases.

Materials and methods. Social damages connected with the respiratory diseases are considered from the point of view of health losses resulting in reduced quality of life, rising prevalence, and mortality.

Economic damages allow the social damages to be presented in numerical expression. Assessment of life cost and loss of the potential years of life (LPYL) are the significant components in these calculations. Mentioned calculations were performed with the help of comparative, medico-statistical, demographic, economic-and-mathematical, structural-and-logical analysis methods of investigation. The official data of the Ministry of Public Health of Ukraine, State Statistics Service and Social Security Fund for 2010-
2015 were used in the study.

Results. We assessed the loss of the potential years of life (LPYL) as a result of premature mortality according to the classes of diseases connected with the respiratory system. Obtained data show that $36.2 \%$ cases of deaths of pneumonia, $35.6 \%$ deaths of malignant tumors of tracheal, bronchi, and lungs, $10.4 \%$ cases of deaths of chronic diseases of lower respiratory tracts make up a significant part in a total number of the loss of the potential years of life. By all selected diseases, at one cases of death, 8.87 years of potential life is lost per year.

Obtained calculations of the quantitative assessments of the loss of the potential years of life with the application of the feedback index of the use of human capital as a cost evaluation of human life (it made up 46413 UAH, or 2124, USD in 2015) allowed to get a sum of economic losses - 11.4 billions UAH, or 523.8 millions USD.

While using the element-by-element approach to the data of 2015, the economic losses of the state because of premature mortality of the respiratory diseases made up 1.2\% GDP, or 24.03 billions UAH.

Keywords: premature mortality, ambient air, cost of life, economic evaluation. муванні втрат через передчасну смерть зокрема. Крім того, це ілюструє ймовірну вигоду від здоров'яохоронних заходів, результатом яких буде скорочення рівня передчасної смертності (взагалі і з певних причин).

Економічні втрати через смертність населення України з урахуванням кількості непрожитих років можна оцінити за допомогою показників потенційної демографії. За цими показниками можна охарактеризувати час, який у середньому передбачається прожити представнику кожної вікової групи, виходячи 3 середньої очікуваної тривалості життя для даного віку. Життєвий потенціал групи людей у віці $\mathrm{m}$ до М на увесь час очікуваної тривалості життя вимірюється у людино-роках і визначається за формулою:

$P(m, M ; 0, w)=\sum_{m}^{M-1} N_{x} * \frac{e_{x}+e_{x}+1}{2}$

де $\mathbf{N}_{\mathbf{x}}$ - чисельність людей у віці х; $\mathbf{e}_{\mathbf{x}}-$ середня тривалість життя для віку $x$.

Якщо в якості $\mathrm{N}_{\mathrm{x}}$ розглядати чисельність померлих у певному віці, можна отримати показник втрат життєвого потенціалу, або втрачених років потенційного життя, який застосовують у демографії для аналізу стану суспільного здоров'я разом 3 традиційними показниками тривалості життя.

Використання показника «втрачені роки потенційного життя» - ВРПЖ має певні позитивні моменти. Насамперед цей показник найбільш повно характеризує стан здоров'я у суспільстві та ефективність функціонування системи охорони здоров'я, оскільки метою її функціонування $є$ запобігання смертності населення у тих її вікових групах, для яких вона не є природною. По-друге, отримані показники втрачених років можна конвертувати у вартісні показники через показник вартості одного року життя людини та продуктивність праці, що дозволить отримати обсяги недовиробленої продукції. Даний показник відповідає вимогам об'єктивності та доступності, що дозволяє використовувати його у динамічних дослідженнях та при розробці стратегічних управлінських рішень в економіці охорони здоров'я та екологічній політиці. Розрахунки застосовуються при обчисленні рекомендованого до використання експертами ВООЗ показника DALY, що являє собою суму років потенційного життя, втрачених через передчасну смерть, та років, проведених у хворобливому (непрацездатному) стані, або погіршення якості життя людини. На теренах України також запропоновано використовувати показник ВРПЖ для оцінки ефективності політики у сфері охорони здоров'я і діяльності системи охорони здоров'я [5].

Кількість ВРПЖ розраховується як сума різниць років між пороговим значенням віку смерті і фактичним віком смерті усіх осіб, померлих протягом року у молодших за граничні вікових інтервалах [6]. Граничні значення обираються дослідниками залежно від цілей. Нами обрано пороговим вік у 70 років, оскільки економічно активний вік визначений на віковому інтервалі 15-70 років.

Виходячи із статистичних даних щодо розміру пенсії через втрату годувальника нами отримано кількісні оцінки витрат на пенсії через втрату годувальника:

$\mathrm{E}_{\mathrm{CM}}=\mathrm{B}_{1 \mathrm{p}} \times$ ВРПЖ $\times$ Р3+ ВРПЖ х ПП х $\mathbf{P 3}+\mathbf{4}_{\text {пом }} \times \mathbf{M}_{\text {ком }}$

де $\mathbf{B}_{\mathbf{1 p}}$ - вартість одного року життя середньостатистичної людини, грн. (середньорічний заробіток = середньомісячна заробітна плата х 12); ВРПж втрачені роки потенційного життя, людино-років; $\mathbf{4}_{\text {пом }}$ чисельність померлих поточного року через захворювання органів дихання, осіб; ПП - річна продуктивність праці (грн.), що вимірюється як співвідношення обсягу ВВП та чисельності зайнятого населення; P3 - рівень зайнятості, \%; М ком - матеріальні виплати сім'ям у зв'язку з втратою годувальника, тобто обсяг сплаченої пенсії через втрату годувальника, грн.

Результати досліджень. Проведено оцінки втрачених потенційних років життя внаслідок передчасної смерті за обраними класами хвороб, які свідчать, що найвагомішим внеском у загальну втрату потенційного життя здійснюють смерті через пневмонію - 36,2\% загальних 
втрат потенційних років життя, злоякісних утворень трахеї, бронхів та легенів - 35,6\%,

хронічних захворювань нижніх дихальних шляхів - 10,4\% загальних втрат років потенцій-

Таблиця 1

Обсяг втрачених років потенційного життя (ВРПЖ, у людино-роках) через передчасну смертність внаслідок

захворювань органів дихання та пов'язаних з ними хвороб, 2015 р., обидві статі

\begin{tabular}{|c|c|c|c|c|c|c|c|c|}
\hline 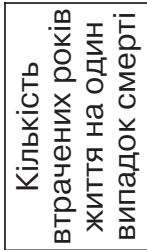 & $\begin{array}{l}10 \\
\infty\end{array}$ & $\bar{r}$ & $\begin{array}{l}N \\
\tilde{m} \\
\tilde{m}\end{array}$ & $\begin{array}{l}\tilde{N} \\
0 \\
\infty \\
\simeq\end{array}$ & $\begin{array}{l}0 \\
0^{\circ}\end{array}$ & $\stackrel{m}{m}$ & $\frac{\infty}{\bar{N}}$ & $\begin{array}{l}\sigma \\
\infty\end{array}$ \\
\hline $\begin{array}{l}\text { த } \\
ழ \\
1 \\
0\end{array}$ & $\frac{\nabla}{\Gamma}$ & 志 & 6 & \begin{tabular}{l}
$\infty$ \\
○ \\
\hdashline
\end{tabular} & 0 & $\begin{array}{l}\mathscr{Q} \\
\stackrel{\leftrightarrow}{\sim}\end{array}$ & 옴 & $\begin{array}{l}\hat{N} \\
\infty \\
0 \\
0\end{array}$ \\
\hline $\begin{array}{l}\dot{0} \\
\vdots \\
0 \\
0\end{array}$ & $\begin{array}{l}\text { ণ } \\
\text { N }\end{array}$ & $\begin{array}{l}N \\
\frac{N}{N} \\
\infty \\
\infty\end{array}$ & 0 & $\begin{array}{l}\infty \\
\text { 巳 } \\
\text { + }\end{array}$ & $\infty$ & 京 & 음 & $\begin{array}{l}\underset{d}{\infty} \\
\infty \\
m \\
m\end{array}$ \\
\hline 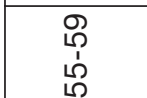 & 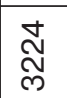 & হ & $\dddot{m}$ & $\frac{\sim}{\infty}$ & $\stackrel{m}{\sim}$ & \begin{tabular}{l}
0 \\
$\infty$ \\
\multirow{1}{0}{}
\end{tabular} & 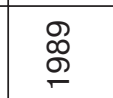 & 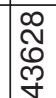 \\
\hline 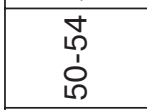 & $\begin{array}{l}\infty \\
\stackrel{\infty}{\infty} \\
\stackrel{\infty}{N}\end{array}$ & $\begin{array}{l}0 \\
1 \\
0 \\
\infty \\
\end{array}$ & $\propto$ & $\begin{array}{l}0 \\
0 \\
\Xi \\
\end{array}$ & 0 & $\begin{array}{l}\text { ㅇ } \\
\stackrel{\wp}{\forall} \\
\end{array}$ & $\frac{8}{\stackrel{0}{N}}$ & $\begin{array}{l}\infty \\
\stackrel{\infty}{N} \\
\text { N } \\
\text { N }\end{array}$ \\
\hline $\begin{array}{l}\text { O } \\
\text { ஸे } \\
\text { ஸे }\end{array}$ & $\begin{array}{l}\text { ஜ్ర } \\
0 \\
\infty\end{array}$ & ণ & ஜ & $\begin{array}{l}0 \\
\infty \\
\infty \\
\square \\
\end{array}$ & N & $\begin{array}{l}8 \\
\stackrel{0}{N}\end{array}$ & 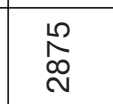 & $\begin{array}{l}\infty \\
\tilde{N} \\
0 \\
\infty\end{array}$ \\
\hline $\begin{array}{l}\text { \& } \\
\text { ๖ं } \\
\text { \& }\end{array}$ & $\begin{array}{l}\infty \\
\infty \\
\infty \\
10\end{array}$ & 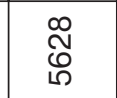 & $\stackrel{N}{\div}$ & 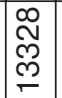 & 0 & Nิ & $\begin{array}{l}\text { ஜ } \\
\text { లె }\end{array}$ & \begin{tabular}{l}
$\infty$ \\
0 \\
$\infty$ \\
\multirow{2}{*}{} \\
N
\end{tabular} \\
\hline $\begin{array}{l}\text { ल } \\
\text { ம } \\
\text { ம }\end{array}$ & $\stackrel{1}{\oplus}$ & ঙ্ & $\stackrel{\sim}{\tilde{m}}$ & $\begin{array}{c}\bar{N} \\
\stackrel{N}{N} \\
\end{array}$ & ल) & 志 & $\begin{array}{l}\stackrel{\text { }}{ } \\
\stackrel{+}{+}\end{array}$ & $\frac{\infty}{\frac{m}{N}}$ \\
\hline $\begin{array}{l}\text { गे } \\
\text { oे }\end{array}$ & $\stackrel{\varphi}{N}$ & $\begin{array}{l}\text { 음 } \\
\end{array}$ & 0 & $\begin{array}{l} \\
\\
\\
\end{array}$ & 0 & o & $\begin{array}{l}\infty \\
\infty \\
\infty \\
\infty\end{array}$ & $\begin{array}{l}\infty \\
\stackrel{\infty}{\rho} \\
0 \\
0 \\
\end{array}$ \\
\hline $\begin{array}{l}\text { న్ } \\
\text { ம் }\end{array}$ & $\stackrel{\mathscr{q}}{\forall}$ & $\underset{N}{N}$ & $\begin{array}{l}0 \\
\infty\end{array}$ & $\begin{array}{l}n \\
N \\
n \\
1\end{array}$ & 0 & $\frac{0}{10}$ & $\frac{\text { m }}{\text { م) }}$ & 余 \\
\hline $\begin{array}{l}\stackrel{d}{N} \\
\text { Ò }\end{array}$ & 0 & $\stackrel{\infty}{\sim}$ & 0 & ஜ & 0 & ๑ & $\begin{array}{l}\stackrel{\circ}{N} \\
\stackrel{N}{N}\end{array}$ & $\begin{array}{l}\text { O } \\
\mathbb{e} \\
\text { ल }\end{array}$ \\
\hline $\begin{array}{l}\frac{0}{1} \\
\text { ம) }\end{array}$ & 0 & 0 & 0 & $\underset{\sim}{\stackrel{\sim}{\sim}}$ & 0 & $\stackrel{\varrho}{\varrho}$ & চ্ & $\underset{\check{g}}{\mathscr{g}}$ \\
\hline$\frac{\dot{\Xi}}{\grave{1}}$ & 0 & 0 & صి & 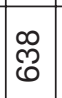 & 0 & $\stackrel{0}{\tau}$ & 유 & 음 \\
\hline م) & 0 & 0 & 0 & $\begin{array}{l}N \\
\infty \\
\infty\end{array}$ & $\widetilde{ఠ}$ & లొ & న్ & $\begin{array}{l}\stackrel{Q}{\mathbb{N}} \\
\stackrel{\sim}{*}\end{array}$ \\
\hline 广্ & 0 & 0 & ষ্ণ & $\begin{array}{l}0 \\
N \\
\infty \\
N\end{array}$ & প্ & 0 & $\stackrel{\infty}{\stackrel{0}{\sim}}$ & 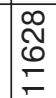 \\
\hline 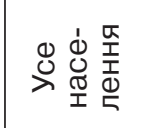 & $\begin{array}{l}\stackrel{L}{\infty} \\
\stackrel{\infty}{上} \\
=\end{array}$ & \begin{tabular}{l}
$\infty$ \\
\multirow{\sigma}{*}{} \\
$\stackrel{\infty}{\infty}$
\end{tabular} & $\begin{array}{l}\infty \\
8 \\
\varnothing \\
0\end{array}$ & $\begin{array}{l}\bar{\varphi} \\
\mathcal{N} \\
\infty\end{array}$ & $\begin{array}{l}0 \\
\text { ભ } \\
6 \\
-\end{array}$ & $\begin{array}{l}\bar{\delta} \\
6 \\
\stackrel{2}{N}\end{array}$ & $\begin{array}{l}\stackrel{L}{N} \\
\infty \\
\text { N }\end{array}$ & 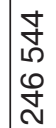 \\
\hline & 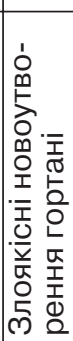 & 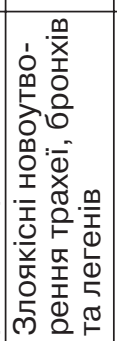 & 돈 & 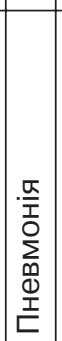 & 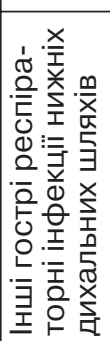 & 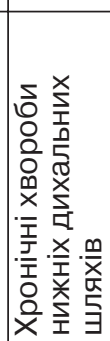 & 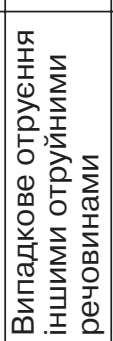 & 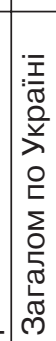 \\
\hline
\end{tabular}

ного життя, отруєння немедичними речовинами - 12,1\%.

Як видно з отриманих розрахунків (табл. 1), найсуттєвіші втрати людино-років спостерігаються у вікових групах 50-54 та 55-59 років, а саме: $15,9 \%$ та $17,7 \%$ загальних втрат людино-років відповідно, або 39258 та 43628 людино-років. Найпоширенішою причиною смерті у цих вікових групах є злоякісні утворення трахеї, бронхів та легенів $(47,3 \%$ та $56,8 \%$ усіх втрат), втрати через пневмонію $(28,3 \%$ та $18,6 \%$ втрачених потенційних років життя) та хронічні хвороби нижніх дихальних шляхів $\quad(11,7 \%$ та 12,6\%). Вагомими втратами потенційних років життя для молоді $€$ втрати через передчасну смерть від пневмонії та грипу. Крім того, розраховано відносний показник кількість втрачених років потенційного життя на один смертний випадок. Так, втрати років життя на одну умовну смерть через такі захворювання, як грип становлять 33,2 роки, інші ГРВІ нижніх дихальних шляхів 60,6 років, випадкове отруєння - 21,8 років. У середньому за усіма обраними захворюваннями на один смертельний випадок втрачається 8,87 років потенційного життя.

При переході від демографічної оцінки до економічної та здійснення оцінки економічних втрат через передчасну смерть виникає питання щодо економічного еквівалента вартості одного року людського життя. Так, при розрахунку фактичних та прогнозних (до 2020 р.) показників втрат через смертність від раку дослідники США використовують фіксовану вартість року людського життя для цієї краї- ни, оцінену у $\$ 150000$ [7]. Проте для співставного використання в інших країнах рекомендують визначати економічну вартість втрат через передчасну смертність як частку від валового внутрішнього продукту (ВВП) [8].

Виходячи з вищезазначеного ми провели розрахунки економічних втрат через передчасну смертність у двох варіантах.

у першому випадку [3] за вартість життя приймався показник віддачі від використання людського капіталу, який виражається показником валового внутрішнього продукту на душу населення, динаміка якого наочно продемонстрована у таблиці 2.

Таким чином, економічні втрати, зумовлені передчасною смертністю внаслідок захворювань дихальних шляхів, можна оцінити як частину недовиробленого ВВП на душу населення. За результатами кількісних оцінок втрат потенційних років життя можна отримати суму економічних втрат через передчасну смертність у 2015 р. у сумі $-11,4$ млрд. грн., або 523,8 млн. дол. США, взявши за вартісну оцінку людського життя суму у 46413 грн., або 2124,7 дол. США. Як видно, сума збитків через передчасну смертність від захворювань органів дихання $є$ досить вагомою.

у другому випадку використано поелементний підхід до оцінки економічних втрат через смертність, зумовлену захворюваннями органів дихання. При цьому витрати діляться на ті, які несуть безпосередньо домогосподарства, та ті, які несе держава.

Витрати домогосподарств проявляються у вигляді недоотриманого доходу (заробітної 
платні) протягом потенційно можливих років життя.

Державні витрати - це насамперед недоотриманий обсяг ток продуктивності праці та чисельності померлих через визначені нами причини, а також суми витрат, пов'язаних з виплатою пенсій особам, які були на утриманні померлого. При оцінці даного показника ми виходили із статистичних показників середнього розміру домогосподарства та певних припущень.

Так, виходячи з того, що пенсії через втрату годувальника отримують малолітні діти до досягнення ними 18-річного віку, було обрано чисельність померлих у віці від 20 до 65-річного віку, які потенційно можуть мати малолітніх дітей або батьЗважаючи на статистичні дані щодо середнього розміру домогосподарств з дітьми, було визначено кількість домогосподарств, що отримують допомогу через втрату годувальника та кількість отримувачів такої пенсії і, відповідно, кількісні показники витрат на пенсії через втрату годувальника.

Оскільки не всі померлі могли б бути зайнятими, було зроблено корегування витрат на заробітну платню та недоотриманого ВВП на рівень зайнятості. Припускаємо, що протягом очікуваної тривалості життя рівень зайнятості визначатиметься на рівні року, на дату якого ми робимо оцінки, тобто у нашому випадку 2015 рік. Отримані результати наведено у таблиці 3.

Показано, що суттєві втрати держави внаслідок передчасної ВВП, який визначається як добуків, які були на утриманні.

смерті через захворювання лише органів дихання, за даними 2015 р., склали 1,2\% ВВП, або 24,03 млрд. грн.

Таким чином, зменшуючи ризик захворювань, які призводять до передчасної смерті, можна домогтися економічного зростання у країні, оскільки людські життя є капіталом країни і складовою національної безпеки.

\section{Висновки}

Кількісна оцінка втрат суспільства внаслідок передчасної смерті дає можливість реально обґрунтувати державну соціальну політику у галузі громадського здоров'я, промислову та екологічну політику, оскільки зниження рівня втрат років людського життя може слугувати об'єктивним показником ефективності інвестицій у цих сферах і формування політики сталого розвитку у країні.

Досягнення економічних вигід для держави завдяки зменшенню втрат від передчасної смертності населення $€$ неможливим без витрат на покращання навколишнього середовища, у тому числі на зменшення викидів в атмосферне повітря, адже ці витрати сприятимуть збереженню та примноженню людського капіталу і, як наслідок, зростанню національного багатства.

\section{ЛІТЕРАТУРА}

1. Уряд збільшив розмір пенсій сім'ям загиблих на Майдані до 8,5 тис. грн. - Режим доступу: http://www.kmu.gov.ua/control/pu blish/article?art id=247891261

2. Быков А.А. О методологии экономической оценки жизни среднестатистического человека

\section{Динаміка ВВП України на душу населення, 2010-2015 рр.} гривні та долари США

\begin{tabular}{|c|c|c|c|c|}
\hline \multirow[t]{2}{*}{ Piк } & \multicolumn{2}{|c|}{ ВВП у національній валюті } & \multicolumn{2}{|c|}{ ВBП у USD на душу населення } \\
\hline & $\begin{array}{c}\text { у фактич- } \\
\text { них цінах, } \\
\text { грн. }\end{array}$ & $\begin{array}{c}\text { відносні прирости } \\
\text { до попереднього } \\
\text { року, \% }\end{array}$ & $\begin{array}{l}\text { номінальне } \\
\text { значення, } \\
\text { USD }\end{array}$ & $\begin{array}{c}\text { відносні прирости } \\
\text { до попереднього } \\
\text { року, \% }\end{array}$ \\
\hline 2010 & 24798 & & 3078,4 & \\
\hline 2011 & 29980 & 20,8 & 3704,8 & 20,3 \\
\hline 2012 & 32480 & 8,4 & 4004,8 & 8,1 \\
\hline 2013 & 33965 & 4,6 & 4187,8 & 4,6 \\
\hline 2014 & 36904 & 10,3 & 3104,6 & $-25,9$ \\
\hline 2015 & 46413 & 25,8 & 2124,7 & $-31,6$ \\
\hline
\end{tabular}

Примітки: до 2013 з урахуванням Автономної Республіки Крим (АРК), після - без урахування АРК та зони антитерористичної операції (АТО). Джерело: сайт Держстату

http://www.ukrstat.gov.ua/ та фінансового порталу «Мінфін» http://index.minfin.com.ua/index/gdp/ (пояснительная записка). - Режим доступа: www.dex.ru/riskjournal/ 2007/2007_4_2/178-191.pdf

3. Нифантова Р.В., Шипицына С.Е. Современные методические подходы в оценке стоимости человеческой жизни. Экономика региона. 2012. № 3. С. 289-294.

4. Карабчук Т.С., Никитина М.В., Ремезкова В.П., Соболева Н.Э. Как оценить стоимость человеческой жизни? Экономическая социология. 2014. Т. 15. № 1. С. 89-106.

5. Рингач Н.О. Громадське здоров'я в Україні як чинник націо-

Таблиця 3

Оцінка економічних збитків держави та домогосподарств через передчасну смертність за рахунок захворювання дихальних шляхів у 2015 році

\begin{tabular}{|l|c|}
\hline \multicolumn{1}{|c|}{ Показник } & 2015 \\
\hline $\begin{array}{l}\text { Середньомісячна заро- } \\
\text { бітна плата, грн. }\end{array}$ & 4195 \\
\hline $\begin{array}{l}\text { Вартість одного року } \\
\text { життя, грн. }\end{array}$ & 50340 \\
\hline $\begin{array}{l}\text { Чисельність населення, } \\
\text { тис. осіб }\end{array}$ & 42675,3 \\
\hline ВВП, млн. грн. & 1979458 \\
\hline $\begin{array}{l}\text { Чисельність зайнятого } \\
\text { населення, тис. осіб }\end{array}$ & 16443,2 \\
\hline $\begin{array}{l}\text { Продуктивність праці, } \\
\text { тис. грн. }\end{array}$ & 120,38 \\
\hline ВРПж, людино-роки & 246544 \\
\hline $\begin{array}{l}\text { Чисельність померлих } \\
\text { внаслідок захворювань } \\
\text { дихальних шляхів, зага- } \\
\text { лом, осіб }\end{array}$ & 27788 \\
\hline Рівень зайнятості, \% & 166,7 \\
\hline $\begin{array}{l}\text { Чисельність померлих у } \\
\text { віці 20-б5 років, осіб }\end{array}$ & 13052 \\
\hline $\begin{array}{l}\text { Середній розмір серед- } \\
\text { ньомісячної пенсії через } \\
\text { втрату годувальника, грн. }\end{array}$ & 1433,1 \\
\hline $\begin{array}{l}\text { Середній розмір домогос- } \\
\text { подарств з дітьми, осіб }\end{array}$ & 3,65 \\
\hline $\begin{array}{l}\text { Кількість домогоспо- } \\
\text { дарств, в яких отримують } \\
\text { пенсії через втрату } \\
\text { годувальника }\end{array}$ & 3575,9 \\
\hline $\begin{array}{l}\text { Кількість дітей, що отри- } \\
\text { мують пенсію через } \\
\text { втрату годувальника }\end{array}$ & 9476,1 \\
\hline $\begin{array}{l}\text { Витрати на пенсії, } \\
\text { млн. грн. }\end{array}$ & 162,9 \\
\hline $\begin{array}{l}\text { ЗП протягом потенцій- } \\
\text { них років життя, } \\
\text { скорегованих на рівень } \\
\text { зайнятості, млн. грн. }\end{array}$ & 7037,1 \\
\hline $\begin{array}{l}\text { Недоотриманий ВВП } \\
\text { протягом потенційного } \\
\text { життя, скорегованого на } \\
\text { рівень зайнятості, млн. грн. }\end{array}$ \\
\hline $\begin{array}{l}\text { Загальні витрати через } \\
\text { передчасну смертність, } \\
\text { (внаслідок захворювань } \\
\text { дихальн. шляхів), млн. грн. }\end{array}$ \\
\hline у о до ВВП \\
\hline
\end{tabular}


нальної безпеки: монографія. К. : вид-во НАДУ, 2009. 296 с.

6. Dicker R., Gathany N. Anderson P., Segal B., Smith S., Thompson Ph. Principles of Epidemiology : 2-nd Edition. SelfStudy Course 3030-G CDC / / US Department of Health \& Human Services, 12/92. Available at : http://pubhealth.spb.ru/EpidD/

7. Yabroff K.R., Bradley C.J., Mariotto A.B., Brown L.M., Feuer E.J. Estimates and Projections of Value of Life Lost From Cancer Deaths in the United States. J Natl Cancer Inst. 2008. № 100 (24). P. 1755-1762.

8. Brown D.W. Economic Value of Disability-adjusted Life Years Lost to Violence: Estimates for WHO Member States. Rev Panam Salud Publica. 2008. № 24 (3). P. 203-209.

\section{REFERENCES}

1. Uriad zbilshyv rozmir pensii simiam zahyblykh na Maidani do 8,5 tys. hrn. [Government Increased a Size of Pensions for the Families of the Dead on the Maidan up to 8.5 thousand $\mathrm{UAH}$. Available at: http://www.kmu.gov. ua/control/publish/article?art_id= 247891261 (in Ukrainian).

2. Bykov A.A. O metodologii ekonomicheskoi otsenki zhizni srednestatisicheskogo cheloveka (poiasnitelnaia zapiska) [On the Methodology of Economic Assessment of the Life of Average Man (Explanatory Note)]. Available at: www.dex. ru/riskjournal/2007/2007 42/ 178-191.pdf (in Russian).

3. Nifantova R.V., Shypitsyna S.Ye. Ekonomika regiona. 2012 ; 3 : 289-294 (in Russian).

4. Karabchuk T.S., Nikitina M.V., Remezkova V.P. and Soboleva N.E. Ekonomicheskaia sotsiologiia. 2014 ; 15 (1) : 89-106 (in Russian).

5. Rynhach N.O. Hromadske zdorovia v Ukraini yak chynnyk natsionalnoi bezpeky: monohrafiia [Public Health in Ukraine as a Factor of National Safety: Monograph]. Kyiv ; 2009 : 296 p. (in Ukrainian).

6. Dicker R., Gathany N. Anderson P., Segal B., Smith S. and Thompson Ph. Principles of Epidemiology : 2-nd Edition. SelfStudy Course 3030-G CDC / US Department of Health \& Human Services, 12/92. Available at: http://pubhealth.spb.ru/EpidD/ 7. Yabroff K.R., Bradley C.J., Mariotto A.B., Brown L.M. and Feuer E.J. J. Natl. Cancer Inst. 2008 ; 100 (24) : 1755-1762.

8. Brown D. W. Rev Panam Salud Publica. 2008 ; 24 (3) : 203-209.

Надійшла до редакції 09.01.2017

\section{ASSESSMENT OF TRAFFIC-RELAIED HUMAN HEALTH RISKS IN DARNYTSKYI AND DNIPROVSKYI DISTRICTS OF KVIV CITY Ananieva O.V.}

ОЦПККА РИЗИКУ ДЛЯ ЗДОРОВ’Я НАСЕЛЕННЯ, ЗУМОВЛЕНОГО ВИКИДАМИ АВТОМОБІЛЬНОГО ТРАНСПОРТУ, НА ТЕРИТОРЇ̈ ДАРНИЩЬКОГО ТА ДНПРОВСЬКОГО РАЙОНВВ м. КИЕВА

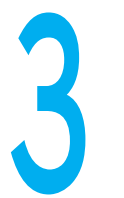

AHAHЬEBA O.B.

ДУ „Інститут громадського здоров'я ім. О.М. Марзєєва

НАMHУ”, м. Київ

УДК 614.71:504.06:616-084

Ключові слова: оцінка ризику, експозиція, автомобільний транспорт, забруднення повітря, органи дихання. а даними Організації Об'єднаних Націй, станом на 2050 рік майже $70 \%$ населення планети житиме у містах [1]. Стрімкі темпи глобалізації несуть суспільству нові позитивні зміни, задовольняючи потреби у доступі до товарів та послуг, соціальних благ і комунікації. Водночас такі аспекти міського життя, як підвищені рівні забруднення довкілля, обмежений доступ до зелених зон, малорухливий спосіб життя стають причиною зростання
ОЦЕНКА РИСКА ДЛЯ ЗДОРОВЬЯ НАСЕЛЕНИЯ, ОБУСЛОВЛЕННОГО ВЫБРОСАМИ АВТОМОБИЛЬНОГО ТРАНСПОРТА, НА ТЕРРИТОРИИ ДАРНИЦКОГО И ДНЕПРОВСКОГО РАЙОНОВ Г. КИЕВА Ананьева О.В.

ГУ "Институт общественного здоровья им. А.Н. Марзеева

Национальной академии медицинских наук Украины"

Целью исследования была оценка риска для здоровья населения от загрязнения атмосферного воздуха выбросами автомобильного транспорта на территории Дарницкого и Днепровского районов г. Киева. Материалы и методы. Для оценки экспозиции, формирующейся за счет выбросов автотранспортных потоков на территории исследования, и расчета соответствующих уровней риска для здоровья была использована методология оценки риска для здоровья населения, рекомендованная к использованию Агентством США по охране окружающей среды. Для расчета усредненных концентраций (1-, 24-часовых и годовых) была использована модель расчета рассеивания концентраций загрязняющих веществ в атмосферном воздухе ISC-AERMOD View v.8.8.9. Расчет загрязнения проведен для 28 автодорог и 6 перекрестков. В работе использованы методы наблюдения и учета по структуре, интенсивности и особенностям движения транспортных потоков, методы статистической обработки данных и методы пространственного анализа данных (ArcMap v. 10.1, Esri).

Результаты. Выполнен расчет рассеивания усредненных концентраций углерода оксида, оксидов азота (в перерасчете на $\mathrm{NO}_{2}$ ), серы диоксида, неметановых углеводородов, взвешенных частиц $P M_{10}$ и формальдегида в 952 рецепторных точках с шагом 250 м, равномерно расположенных на территории исследования. На основании полученных уровней экспозиции рассчитаны показатели неканцерогенного риска (коэффициенты опасности НQ) для острого и хронического ингаляционного воздействия, а также суммарный неканцерогенный риск (HI). При условии острого воздействия определено превышение допустимого уровня (HQ $\geq 1)$ только для $P M_{10}$ в районе Дарницкой площади $(H Q=1,2)$ и проспекта Соборности $(H Q=1,4)$. Для условий хронического воздействия установлено превышение допустимого уровня коэффициентов опасности (HQ $\geq 1)$ для оксидов азота (в перерасчете на NO2) - HQ от 1,26E-02 до 2,07E+00; неметановых углеводородов HQ от 1,58E-02 до 3, 18E+00; $P M_{10}-H Q$ от 5,53E-03 до 1,27E+00. Для остальных веществ коэффициенты опасности при хроническом воздействии были на допустимом уровне $(H Q<1)$, а риск для здоровья минимальным. Суммарный неканцерогенный риск (HI) для условий хронического воздействия определен в диапазоне от 4,04E-02 до $5,43 E+00$, что свидетельствует о возможности возрастания частоты негативных реакций со стороны органов дыхания в 1,5-5,4 раза.

Ключевые слова: оценка риска, экспозиция, автомобильный транспорт, загрязнение воздуха, органы дыхания.

() Ананьєва О.В. СТАТТЯ, 2017. 